\title{
Comment
}

Neuroepidemiology 2013;41:62-63

DOI: $10.1159 / 000350016$

\section{Amyotrophic Lateral Sclerosis Descriptive Studies: Not Only Rates and Frequencies}

\section{Giancarlo Logroscino}

Neurodegenerative Disease Unit, Department of Neurosciences and Sense Organs, University of Bari, Bari, and Department of Clinical and Research Neurology, Azienda Ospedaliera Pia Fondazione Panico, Tricase, Italy

In this issue of Neuroepidemiology, Drigo et al. [1] assess the incidence and prevalence of amyotrophic lateral sclerosis (ALS) in Friuli Venezia Giulia, a north-eastern region in Italy, with a population of about 1.2 million, bordering Slovenia to the east and Austria to the north. This is an aging population with about $22 \%$ of subjects over 65 years old.

The study design was retrospective within a population-based network of multiple sources. The period of observation lasted almost a decade, from 2002 to 2009. The methodology used in the Friuli registry is similar to the registries of EURALS, the consortium of European population-based registries [2-6] in two main characteristics: (1) the reference population is large in a well-defined geographic area, and (2) multiple sources were used for case ascertainment, including the Regional Health Database, a good example of the efficacy of administrative data for epidemiological research. The authors did not use the El Escorial criteria for the classification of cases, and the design was not prospective. However, the use of an extensive search for sources for case inception made the final results of this study on incidence $(2.7 / 100,000)$ similar to the incidence found in most recent studies in Europe from the Piedmont $(2.90 / 100,000)$ [7] and Ireland $(2.0 / 100,000)$ [8].

All recent studies show that the incidence is quite homogeneous in Europe and the USA [9]. The most likely estimates of the incidence are between 2 and 3 cases per 100,000 person-years. The cluster of Guam disappeared some years ago, and the rates in Guam since the late 1980s are similar to most of the other regions in the world [10]. A recent study showed the highest incidence in the Kiji pensinsula in Japan, in the city of Oshima, with 9.45/100,000 (95\% confidence interval 7.39-26.29). This report, however, is based on a long period of observation in a very small base population (20,000 inhabitants).

An incidence rate of 1.4/100,000 was reported both in Catalonia [11] and in Sicily [12] similar to what has been reported previously in Apulia $(1.7 / 100,000)$. Overall, the incidence in these southern registries is about half of what has been reported in Friuli and Piedmont. It is possible that the incidence of ALS in some areas around the Mediterranean is lower than in central and northern Europe.
The reported prevalence in this study is around 5/100,000, lower than we expected based on other studies and the median survival of ALS patients. Similarly to the incidence, the prevalence peak is in the older subjects between the ages of 65 and 74 years. A recent survey from the province of Modena (Italy) indicates almost doubling of the prevalence figures in recent years (from $5.8 / 100,000$ in the year 2000 to $11.2 / 100,000$ in the year 2009). All these data confirm that the ALS epidemiological figures are expected to go up in the future years with the aging of the general population or hopefully also due to the improved survival. The prevalence is important for the organization of resources in secondary and tertiary health systems to plan the health care of these patients.

Based on this experience, in Friuli the authors are building up a population-based registry that will join EURALS. In an ideal setting at least part of these population-based registries should be the basis of a system of permanent surveillance of ALS. Surveillance is defined as 'the ongoing systematic collection, analysis, interpretation, and dissemination of data, reflecting the current status of a community or population' [13]. This may be considered excessive for a rare disease like ALS, but this is the basis to disentangle the etiology and also to find a better therapy.

Population-based studies have been useful in defining clinical characteristics and prognostic indicators in ALS [14]. However, many new epidemiological questions remain that probably cannot be resolved by any of the existing population-based data sets. The recent reports about C9ORF76 and the heterogeneity of the clinical phenotype $[15,16]$ indicate that the attention of future registries should shift from pure motoneuron disease to more complex features involving cognitive impairment. Unfortunately, although not insurmountable, the obstacles for such studies both in terms of implementation and interpretation will be considerable. Many hints from the study of Drigo et al. [1] show that ALS descriptive studies are not only about rates and frequencies.

\section{References}

1 Drigo D, Verriello L, Clagnan E, Eleopra R, Pizzolato G, Bratina A, D’Amico D, Sartori A, Masè G, Simonetto M, Lazzarino de Lorenzo L, Cecotti L, Zanier L, Pisa F, Barbone F: The incidence of amyotrophic lateral sclerosis in Friuli Venezia Giulia, Italy, from 2002 to 2009: a retrospective population-based study. Neuroepidemiology 2013;41:5461

2 Scottish Motor Neuron Disease Register: A prospective study of adult onset motor neuron disease in Scotland. Methodology, demography and clinical features of incident cases in 1989. J Neurol Neurosurg Psychiatry 1992;55:536-541.

3 Traynor BJ, Codd MB, Corr B, Forde C, Frost E, Hardiman O: Incidence and prevalence of ALS in Ireland, 1995-1997: a population-based study. Neurology 1999;52:504-509.

-4 Piemonte and Valle d'Aosta Register for Amyotrophic Lateral Sclerosis (PARALS): Incidence of ALS in Italy: evidence for a uniform frequency in Western countries. Neurology 2001;56:239-244.

\section{KARGER}

E-Mail karger@karger.com

www.karger.com/ned
2013 S. Karger AG, Basel

$0251-5350 / 13 / 0411-0062 \$ 38.00 / 0$
Giancarlo Logroscino, $\mathrm{MD}, \mathrm{PhD}$

Neurodegenerative Disease Unit

Department of Neurosciences and Sense Organs, University of Bari

IT-70121 Bari (Italy)

E-Mail giancarlo.logroscino@uniba.it 
5 Logroscino G, Beghi E, Zoccolella S, Palagano R, Fraddosio A, Simone IL, Lamberti P, Lepore V, Serlenga L: SLAP Registry: incidence of amyotrophic lateral sclerosis in southern Italy: a population based study. J Neurol Neurosurg Psychiatry 2005;76:1094-1098.

6 Beghi E, Logroscino G, Chiò A, Hardiman O, Mitchell D, Swingler R, Traynor BJ, EURALS Consortium: The epidemiology of ALS and the role of population-based registries. Biochim Biophys Acta 2006;1762:1150 1157.

7 Chiò A, Mora G, Calvo A, Mazzini L, Bottacchi E, Mutani R, PARALS: Epidemiology of ALS in Italy: a 10-year prospective population-based study. Neurology 2009;72:725-731.

$>8$ O’Toole O, Traynor BJ, Brennan P, Sheehan C, Frost E, Corr B, Hardiman O: Epidemiology and clinical features of amyotrophic lateral sclerosis in Ireland between 1995 and 2004. J Neurol Neurosurg Psychiatry 2008;79:30-32.

$>9$ Logroscino G, Traynor BJ, Hardiman O, Chiò A, Mitchell D, Swingler RJ, Millul A, Benn E, Beghi E, EURALS: Incidence of amyotrophic lateral sclerosis in Europe. J Neurol Neurosurg Psychiatry 2010;81:385-390.

10 Plato CC, Garruto RM, Galasko D, Craig UK, Plato M, Gamst A, Torres JM, Wiederholt W: Amyotrophic lateral sclerosis and parkinsonism-dementia complex of Guam: changing incidence rates during the past 60 years. Am J Epidemiol 2003;157:149-157.

11 Pradas J, Puig T, Rojas-García R, Viguera ML, Gich I, Logroscino G: Amyotrophic lateral sclerosis in Catalonia: a population based study. Amyotroph Lateral Scler Frontotemporal Degener 2013, E-pub ahead of print.

12 Ragonese P, Cellura E, Aridon P, D’Amelio M, Spataro R, Taiello AC, Maimone D, La Bella V, Savettieri G: Incidence of amyotrophic lateral sclerosis in Sicily: a population based study. Amyotroph Lateral Scler 2012;13:284-287.
13 Thacker SB, Berkelman RL: Public health surveillance in the United States. Epidemiol Rev 1988;10:164-190.

14 Logroscino G, Traynor BJ, Hardiman O, Chio’ A, Couratier P, Mitchell JD, Swingler RJ, Beghi E, EURALS: Descriptive epidemiology of amyotrophic lateral sclerosis: new evidence and unsolved issues. J Neurol Neurosurg Psychiatry 2008;79:6-11.

15 Renton AE, Majounie E, Waite A, Simón-Sánchez J, Rollinson S, Gibbs JR, Schymick JC, Laaksovirta H, van Swieten JC, Myllykangas L, Kalimo H, Paetau A, Abramzon Y, Remes AM, Kaganovich A, Scholz SW, Duckworth J, Ding J, Harmer DW, Hernandez DG, Johnson JO, Mok K, Ryten M, Trabzuni D, Guerreiro RJ, Orrell RW, Neal J, Murray A, Pearson J, Jansen IE, Sondervan D, Seelaar H, Blake D, Young K, Halliwell N, Callister JB, Toulson G, Richardson A, Gerhard A, Snowden J, Mann D, Neary D, Nalls MA, Peuralinna T, Jansson L, Isoviita VM, Kaivorinne AL, Hölttä-Vuori M, Ikonen E, Sulkava R, Benatar M, Wuu J, Chiò A, Restagno G, Borghero G, Sabatelli M, ITALSGEN Consortium, Heckerman D, Rogaeva E, Zinman L, Rothstein JD, Sendtner M, Drepper C, Eichler EE, Alkan C, Abdullaev Z, Pack SD, Dutra A, Pak E, Hardy J, Singleton A, Williams NM, Heutink P, Pickering-Brown S, Morris HR, Tienari PJ, Traynor BJ: A hexanucleotide repeat expansion in C9ORF72 is the cause of chromosome 9p21-linked ALS-FTD. Neuron 2011;72: 257-268.

16 DeJesus-Hernandez M, Mackenzie IR, Boeve BF, Boxer AL, Baker M, Rutherford NJ, Nicholson AM, Finch NA, Flynn H, Adamson J, Kouri N, Wojtas A, Sengdy P, Hsiung GY, Karydas A, Seeley WW, Josephs KA, Coppola G, Geschwind DH, Wszolek ZK, Feldman H, Knopman DS, Petersen RC, Miller BL, Dickson DW, Boylan KB, Graff-Radford NR, Rademakers R: Expanded GGGGCC hexanucleotide repeat in noncoding region of C9ORF72 causes chromosome 9p-linked FTD and ALS. Neuron 2011;72:245-256. 